\title{
7. Cyrano and the Experimental Discourse
}

As Leonard Bloomfield has shown, scientific research begins with a set of sentences which point the way to certain observations and experiments, the results of which do not become fully scientific until they have been turned back into language, yielding again a set of sentences which then become the basis of further explorations into the unknown.

-Benjamin Lee Whorf, Language, Thought, and Reality

Francis Bacon asserts that a true science elaborates its axioms from facts ("particulars") by means of a "certain method and rule." This method is nothing less than a new class of discourse. We may justly say, with Whorf and others, that "science" in this view is neither more nor less than the elaboration of a system of sentences. To say that scientific research begins in a series of sentences which indicate "the way to certain observations and experiments" is merely to repeat Bacon's idea of "literate experience." It is Bacon, too, who is at the root of the idea that such experiments are only "scientific" when their results have once again been placed in the discourse which originated those experiments (and observations), in such a way that the process will be repeated indefinitely: "first ascending to axioms, then descending to works."

Bacon's is not, then, an idea of science limited to a relatively brief moment at the beginning of the seventeenth century. It remains our

1. The phrase "experimental method" can obviously be invested with a diversity of meanings (cf. Ian Hacking, The Emergence of Probability: A Philosophical Study of Early Ideas about Probability, Induction, and Statistical Inference [Cambridge, 1975], pp. 35-37). My use of the phrase "experimental discourse" or "discourse of experimentalism," as in the previous two chapters and henceforward, is almost as a synonym for the phrase "analytico-referential discourse." It is rather more restrictive in that it seeks to specify the model of that discourse, with specific reference to the development of the 'natural sciences' from the early seventeenth century on. Its precise meaning and implication here is, of course, part of the point of my entire discussion.

226 
own. It remains indeed by and large the underlying premise behind all our discourses of truth and, therefore, behind all the forms of what we term 'knowledge.' For Baconian experimentalism is not sim$p l y$, as is often claimed, the active manipulation and 'forcing' of natural phenomena. Such manipulation is dependent, as it is for Galileo, on prior theory. Indeed, in his autobiography, John Wallis deliberately associated Galileo and Bacon as the model of "the New Philosophy or Experimental Philosophy" to be pursued by the group which was to form the nucleus of the Royal Society. ${ }^{2}$ When Norwood Hanson argues, in a widely held contemporary view, that all observational terms are "theory-laden," he repeats Bacon's or Galileo's position: for in their 'dialectic of knowing' there can logically be no point of beginning either. ${ }^{3}$ Thus a relatively recent schematization of our scientific methods depicts an order that could have been derived directly from the new discourse invented (found?) by Bacon, Galileo, and their contemporaries:

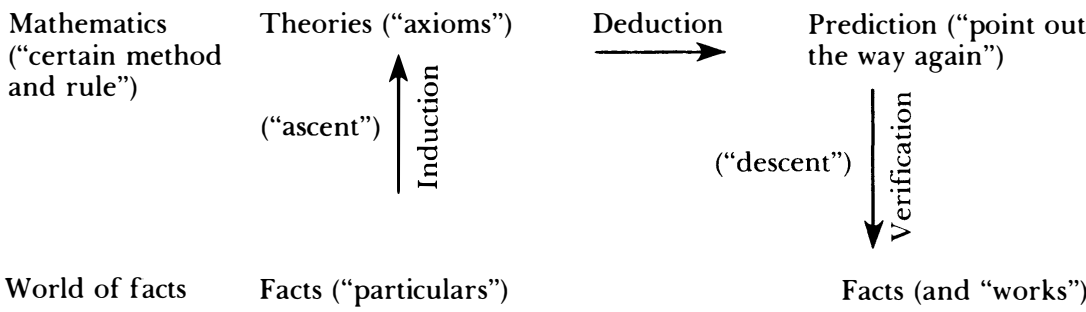

This diagram, without the Baconian analogues, is offered by John Kemeny as the fundamental system of scientific research in a text widely used in North American universities. ${ }^{4}$ The analytical order which Kepler places, so to speak, in the margin of his text or seeks to incorporate as merely another piece in an overall organization (in the Harmonice); the method which Bacon and Galileo work out as a new space of discourse for which they must initially take responsibility as master-this order becomes with Cyrano the fundamental structure of a literary text. We may add that its doing so in the discursive type called 'literature' is sign that it has done so elsewhere. It is becoming generalized as the only form that can be taken by true knowledge, and the responsibility of enunciation, as I termed it earlier,

2. Quoted by Charles Webster, The Great Instauration: Science, Medicine, and Reform, 1626-166o (London, 1975), p. 56 .

3. Norwood Hanson, Patterns of Discovery (Cambridge, 1965). The idea of all description and observation as "theory-laden" is the basic matter of this book.

4. John J. Kemeny, A Philosopher Looks at Science (New York, 1959), p. 86. 
has been replaced by a notion of discursive objectivity (a replacement we see occurring from the very outset in the early works of Bacon, in Galileo, in Descartes .... ).

Following the Galilean model, the order of Cyrano's Voyage dans la lune, not to say its sequel the Voyage au soleil, is that of an uninterrupted series of experimental sequences, each of which is composed of four (or possibly five) elements: ${ }^{5}$ (1) The first element repeats Galileo's epochal gesture of turning his telescope toward the moon. It is the phase of observation. Here the medium is always the naked eye. Its object, of course, is not always the moon or other celestial body, although it is in the first sequence-as is no more than appropriate. (2) The second element is an attempt to control what is perceived as exterior by 'internalizing' it, as though to possess it, and to express the resulting 'conceptualization' in (as) language, a sentence. It is an attempt to give meaning to the initial observation within an already known discourse, an attempt to explain. This element in the sequence continues on to a kind of 'double take,' resulting in a reappraisal of the initial attempts to conceptualize. We have a critical examination of the proposed theses, terminating in a hypothesis susceptible of verification by the undertaking of specifiable "works." (3) The third element is the carrying out of the experiment whose intention is to test the abstraction or the hypothesis put forward in the second element of the sequence. This is the descent to works that follows the ascent to axioms of the first two elements. It represents an attempt to close the distance between mind and events in the

5. The textual history of L'autre monde is complicated: even its title is variable. The Histoire comique des estats et empires de la lune was published in $16_{57}$, after Cyrano's death, by his friend Henri Le Bret, in an avowedly expurgated version. Copies of the manuscript are known to have circulated as early as $1649-50$. Two of these are still extant, one in Munich, one in Paris. The basic critical edition of the two novels remains that of Frédéric Lachèvre in the first volume of Les oeuvres libertines de Cyrano de Bergerac, 2 vols. (Paris, 1921). For the text of the Lune alone the definitive edition is now L'autre monde ou les estats et empires de la lune, ed. Madeleine Alcover (Paris, 1977). Cyrano is increasingly published. I have however continued to use a readily available contemporary edition of both: Cyrano de Bergerac, Histoire comique des état et empire de la lune et du soleil, ed. Claude Mettra and Jean Suyeux (Paris, 1962); page citations will appear in the text, preceded by an F. The English edition cited is Cyrano de Bergerac, Other Worlds: The Comical History of the States and Empires of the Moon and Sun, tr. Geoffrey Strachan (London, 1965), and page citations appear in the text preceded by an $\mathrm{E}$. These texts both give the 1657 edition with the variants from the Paris MS added or substituted, as the case requires. The English includes one or two variants from the Munich MS. Because I am referring essentially to the French, I have omitted these last. For the same reason, I have on occasion silently brought the English closer to the French original whenever my point requires it. In four cases it seemed useful to provide the full text of the French in a note. I will refer to the novels as the Voyages, in accordance with what is now customary. 
world, and to compose a discourse adequate to things. (4) Finally comes the confirmation (full or partial) of the adequate relationship between hypothesis and particulars. It leads always to a new observation and a new experimental sequence.

The first of these sequences starts without delay from the first word of the novel:

The moon was full, the sky was cloudless, and it had already struck nine. We were returning from Clamard, near Paris, where the younger Monsieur de Cuigy, who is the squire, had been entertaining myself and several of my friends. Along the road we amused ourselves with the various speculations inspired by this ball of saffron. All our eyes were fixed on the great star. One of our number took it for a garret window in heaven, through which the glory of the blessed could be glimpsed. Another assured us that it was the round, copper ironing-board on which Diana presses Apollo's collars. Another that it might be the sun itself, having cast off its rays in the evening, watching through a peephole to see what happened on earth in its absence. "And as for me," I told them, "I will gladly add my own contribution to your transports. I am in no way diverted by the ingenious fancies with which you flatter time, to make it pass more quickly, and I believe that the moon is a world like ours, which our world serves as a moon." Some of the company treated me to a great outburst of laughter. "And that, perhaps," I said to them, "is just how someone else is being ridiculed at this very moment in the moon for maintaining that this globe here is a world." But although I informed them that Pythagoras, Epicurus, Democritus and, in our own age, Copernicus and Kepler had been of the same opinion, I merely made them laugh more heartily.

Nevertheless this notion, the boldness of which matched the humour I was in, was only fortified by contradiction and lodged so deeply in my mind that for all the rest of the way I remained pregnant with a thousand definitions of the moon of which I could not be delivered. As a result of upholding this burlesque belief with half-serious arguments, I had almost reached the stage of yielding to it already, when miracle or chance, Providence, Fortune, or perhaps what will be called a vision, fiction, chimera, or madness if you will, afforded me the opportunity

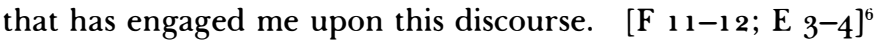

6. "La lune était en son plein, le ciel était découvert, et neuf heures du soir étaient sonnées, lorsque, revenant de Clamart près Paris, où Monsieur de Cuigy le fils, qui en est seigneur, nous avait régalés plusieurs de mes amis et moi, les diverses pensées que nous donna cette boule de safran nous défrayèrent sur le chemin, de sorte que les yeux noyés dans ce grand astre, tantôt l'un le prenait pour une lucarne du ciel par où l'on entrevoyait la gloire des bienheureux, tantôt un autre assurait que c'était la platine où Diane dresse les rabats d'Apollon; un autre, que ce pouvait bien être le soleil lui-même, qui s'étant au soir dépouillé de ses rayons, regardait par un trou ce qu'on faisait au monde quand il n'y était pas. 'Et moi, leur dis-je, qui souhaite mêler 
So begins the narration of the first Voyage. The experimental elements are here articulated in near exemplary fashion. The first observation of the moon leads directly into an attempt at 'explanation' that initially takes the form of a series of 'myths,' or 'pieces' of mythology. These attempts are closed and in the form of a subjectpredicate definition: the moon is a "garret window," an "ironingboard," a "peep-hole," each suggested predicate being an element from a different mythology. These suggestions try to seize the moon and place it as a piece of the world into some previously elaborated discourse. The material image of the moon would serve only to fix more clearly the parameters of that discourse, for it is evident that none of these tell us anything whatever about the moon itself. Of course, all we see here are these particular pieces of a potential discourse of patterning. For reasons which will become clear in Chapter 8 , they go no further than this. The fundamental reason is that the elements of myth are now themselves being aligned with the discourse of analysis and referentiality. They will be taken up later in the characters of Elijah, Socrates, and possibly Campanella, each in turn rejected, displaced, or simply put in doubt. But I will come back to this.

For the present, then, we are given pieces of a Christian myth concerning a Heaven of the bienheureux, a pagan myth concerning Diana and Apollo (there is a second one of this type suggested in the Munich manuscript concerning Bacchus), and an animistic myth in which the sun watches the activities of human beings. In a way the last of them does perhaps lead toward the new cosmological system which places the sun at the center of a mass of bodies whose motion it controls, and it does therefore lead the reader toward the narrator's own suggestion.

In this first series of suggestions, then, we can see a fairly exact

mes enthousiasmes au vôtres, je crois sans m'amuser aux imaginations pointues dont vous chatouillez le temps pour le faire marcher plus vite, que la lune est un monde comme celui-ci, à qui le nôtre sert de lune.' Quelques-uns de la compagnie me régalèrent d'un grand éclat de rire. 'Ainsi peut-ëtre, leur dis-je, se moque-t-on maintenant dans la lune de quelque autre qui soutient que ce globe-ci est un monde.' Mais j'eus beau leur alléguer que Pythagore, Epicure, Démocrite et, de notre âge, Copernic et Képler, avaient été de cette opinion, je ne les obligeai qu'à rire de plus belle.

"Cette pensée cependant, dont la hardiesse biaisait à mon humeur, affermie par la contradiction, se plongea si profondément chez moi, que, pendant tout le reste du chemin, je demeurai gros de mille définitions de lune, dont je ne pouvais accoucher: de sorte qu'à force d'appuyer cette croyance burlesque par des raisonnements presque sérieux, il s'en fallait peu que je n'y déférasse déjà, quand le miracle ou l'accident, la Providence, la Fortune, ou peut-être ce qu'on nommera vision, fiction, chimère, ou folie si on veut, me fournit l'occasion qui m'engagea à ce discours." 
illustration of Bachelard's critique of naïve observation, of "illiterate" experience: "The first experience or, to speak more precisely, the first observation is always a first obstacle to scientific culture. Indeed, this first observation is accompanied by a wealth of images; it is picturesque, concrete, natural, facile. All that has to be done is describe it and marvel at it. It is then believed to be understood." Nonetheless, Bachelard's claim that "there is rupture and not continuity between observation and experimentation" is not borne out altogether by the development I see in the series of suggestions put forward by the narrator's companions. For the last of these does appear to lead toward the implications of the narrator's own belief.

To be sure, the narrator's hypothesis is not founded in a fixed system which would 'absorb' the material image of the moon as Campanella's City absorbs its pieces of new knowledge into its closed structure. On the contrary, it suggests the possibility of a system of knowing whose models change and 'expand' with each new piece. It supposes a continual exchange between the seer and the seen, for the hypothesis is proposed with the implicit premise that it can be tested: it is not just a way of passing time. The way this hypothesis is presented differs from the form taken by the other suggestions. The moon is thought to be like the earth, the earth like the moon ("la lune est un monde comme celui-ci, à qui le nôtre sert de lune").

It has been claimed that this clause, and the reversibility it proposes between the earth and the moon, their 'like-ness,' introduces a "logic of relativity." 8 This phrase, in the present context, does not imply that the status of a phenomenon depends on the position of the observer, but simply that the position of the observer limits his knowledge of the thing. This provides both more and less freedom of hypothesis: less, because it can no longer be assumed that a hypothesis is verified once and for all when it has been incorporated into some 'knowledge system,' since that system is limited; more, because within those limits any hypothesis susceptible of verification may reasonably be put forward. In the present instance, for example, there is no possible reason to suppose that there is some absolute order in which the earth would be of a physical composition different from that of the rest of the universe, or that there are not other habitable planets. It is assumed, a priori, that if the observer can change his position he will gain new knowledge.

The hypothesis is assumed to be open to proof by some kind of

7. Gaston Bachelard, La formation de l'esprit scientifique: Contribution à une psychanalyse de la connaissance objective, 7 th ed. (Paris, 1970), p. 19.

8. Maurice Laugaa, "Lune, et l'Autre," Poétique, no. 3 (1970), p. 285. 


\section{2 - The Discourse of Modernism}

activity which, in this case, depends on a technical achievement whose very elaboration would be part of the proof. This, indeed, is what is demonstrated at the conclusion of the first experimental sequence in Cyrano's Voyage dans la lune: the landing in New France (the third element being the narrator's first flight). The relativity in question, then, simply indicates that our knowledge of a thing is 'relative' to our ability to extend the means of our knowledge and to our understanding that this knowledge depends on where we are and what we do with regard to the thing. 'Relativity' is doubtless a misleading word for what is essentially the Baconian exchange between particulars and axioms.

This does not seem to necessitate any kind of 'rupture' between the propositions of the companions and that of the narrator himself. Certainly there is development. By definition, the only way one could prove (or disprove) the first would be by dying and going to Heaven, while the second would require an acquaintance with the pagan gods in question. In both cases, the discourse to which they belong places a taboo on the passage and the acquaintance in question. This does not apply, however, in the case of the third proposal, which could be proven or disproven by the same means as the narrator's own, even though there is no suggestion that it should be: it does not altogether imply a closed system (though it may depend on one in practice). Perhaps this is why the first two propositions correspond respectively to the characters of Elijah and the demon of Socrates, while the third corresponds to that of Campanella.

A certain ambiguity remains, for the "great outburst of laughter" would seem to emphasize clearly the distance between the first three proposals, caught up to a greater or lesser degree in closed discourse, and that of the narrator, insisting on a process of verification guided by discourse but whose means (observation and experiment) are outside it. Indeed, the narrator appears to insist upon that distance: "Nevertheless this notion, the boldness of which matched the humour I was in, was only fortified by contradiction and lodged . . . deeply in my mind."

It seems to me that this ambiguity corresponds to a similar uncertainty we have already seen in Bacon: on the one hand the discourse is completely objective and therefore needs no 'personal' authority, while on the other it is totally unfamiliar and it remains necessary to convince prospective users of its objectivity. Since such users are confronted with a quite new and different discursive space, they cannot hope to understand unless they are first reduced to a 'clean slate,' and in that case conviction can occur only after the discourse has 
been inscribed on that slate by its master. Is the discourse 'objective,' or does it create its own objects? Does its acceptance depend on an authoritarian imposition (however enlightened), or is it so related to the order of the world as to be the 'natural' discourse of truth?

The first three proposals in this second element of the first experimental sequence of the novel do not succeed in providing an acceptable (and demonstrable) meaning in terms of any familiar discourse-they remain "imaginations pointues"-and the narrator has recourse to an unfamiliar one. When he states it, the others ridicule him. The narrator might well have observed that the previous suggestion already inclines toward a new cosmology and certainly does not preclude the need for, and the possibility of, experiment. But the point perhaps is that the discovery of a "new face of bodies" does require a new class of discourse, however unwilling to admit it may be those who urge such a new class upon their contemporaries. The lack of clear distinction between the proposals in Cyrano's novel, and yet the apparent claim of rupture (the emphasis on the growing laughter and on contradiction), match Bacon's bewilderment as to how to communicate his new discourse: "I do not know how to convince you."

The ambiguities I have mentioned as regards the relation of the experimental discourse with its predecessor(s) correspond to one within the discourse itself. If this new discourse is to function it requires its method and its axioms; to produce method and axioms it needs the observation of "particulars." The dilemma is that of the chicken and the egg. Bacon 'solves' it by the necessary but implicit assumption that the "ascending" and "descending" process is always underway. In this first sequence of Cyrano's novel it is solved by running through a variety of discursive possibilities until one is found which does not seal the answer in a ready-made discourse, in a past superstition or authority, but which "points out the way again to new particulars." This pointing out demands a recourse to "works."

That this interaction with the world is possible indicates the incorporation of an essential axiom of the Baconian discourse which the Englishman expressed most clearly perhaps in the negative: the rejection of that "exalted but deceitful view" which is "the doctrine that truth is the native inhabitant of the human mind, not something that comes into it from outside, and that the sciences do not inform the understanding but merely awaken it." Bacon refers to the view thus rejected as "this error or (to give it its true name) this alienation of the mind" (VII.115: $C V$ ). Truth, in the opposite view, which is as 


\section{4 - The Discourse of Modernism}

much that of the narrator of the Lune as it is of Bacon, is always the result of the interchange between mind and particulars.

The desire to find out the true nature of the moon is appropriate, therefore, only if, as here, it leads to a question that can be resolved by showing, through "works," that the hypothesis produced by the desire corresponds with facts: might the moon not have attributes in all ways similar to those of the earth, since it has similar outward appearance? As Bacon had put it: "For to form judicious wishes is as much a part of knowledge as to ask judicious questions" (VIII.329: $N O$, II.xlix). Only the narrator obeys this stricture, all the others "flying off" to those imponderable "generalizations" which Bacon so condemns.

In Cyrano's novel, as in Bacon's or Descartes's philosophy, the new discourse gets under way by showing that the familiar discourse(s) are all negative instances of a true knowledge. What makes the discourse of experimentalism the only one suitable for a true knowledge is precisely what also enables its particular truths to be received as parts of such a knowledge: the assumption that the discourse has exhausted all the negative instances. In such a way all the ambiguities - the relation of discourse to its recipients, the relation of discourse to its objects, the relation of discourse to its enunciation, the relation of discourse in process to the axioms making possible that process - are laid to rest at once, and in the same way: by excluding all nonverifiable assertions and all negations or contradictions of its own assertions, once the assertions have been verified. It is assumed that particulars will verify (or falsify) an assertion once and for all, and it is then more or less clear what is and what.is not permissible in the discursive space of experimentalism. It must be susceptible of being said to be 'true' or 'false' in terms of facts outside discourse, and it must be in accordance with a system of axioms which have themselves supposedly been verified by the same means. Once again, the difficulty is to get all this under way.

At the end of this second element in the first experimental sequence we are examining, the Voyage underscores the importance of the elaboration of this discourse. That it should choose to do so is not surprising, for it is apparent that this first sequence is not simply an example of the order of experimentalism but also the performance in miniature of the establishment of the whole class of the analyticoreferential. The narrator insists on the relation of interior and exterior, emphasizing not only the observation of particulars but also the interiority of the process that seeks to perceive their order: "notion," "humour," "lodged so deeply in my mind," the metaphor of preg- 
nancy and birth. These are themselves set into a further relation with a third term which, as we have seen in Bacon, subsumes and 'validates' (by its 'method' and axioms once verified) the other two: that of discourse itself.

For there occurs at this point in the novel the rather interesting aside to the reader that concludes the long quotation above. The Paris manuscript of the novel is even more explicit that the passage is indeed an aside to the reader: "I remained pregnant with a thousand definitions of the moon of which I could not be delivered; and as a result of upholding this burlesque belief with serious arguments, I almost persuaded myself. But listen, reader, to the miracle or accident used by Providence or fortune to convince me of it." ${ }^{\prime 9}$ Still, in the printed version the "on" of "on nommera" (translated as "will be called") is evidently an appeal to the reader's consideration, though it is made more apparent in the text just quoted by the words "listen, reader" ("écoute lecteur"). In the same way, the phrase "burlesque belief" ("croyance burlesque") forms a commentary by the narrator on what he regards as the evident opinion of the reader toward the suggestion he has made concerning the moon. It will be the same as that of his companions for the very simple reason that the reader, too, occupies an older and more familiar discursive space. By the aside the reader's attention is drawn not only to the clash of discourses but also (and possibly more important at this point) to the fact that he is reading a writing in the process of its elaboration.

An integral part of this aside is a 'heretical' lumping together of miracle and chance, of providence and fortune, which sends us back to the myths of which we have already been reminded: the Christian, the pagan, the animistic. It sends us back, that is to say, to the content of the familiar discourses used in the novel's initial discussion. So far as the narrator is concerned, one might as well ascribe his finding Cardano's book open at the very page that treats of inhabitants of the moon to any one or all of these agencies ("peut-être ce qu'on nommera ... si on veut"), implying that none of them is responsible, and that the attempt to find such causes is irrelevant. In a way the reference to miracles and providence-both of them notions tending to reflect that universe of analogies where everything is linked and works toward the 'ultimate meaning' which is God Himself-by opposing the reference to chance and fortune resumes at another level the dispute between the narrator and his friends.

9. Cyrano de Bergerac, Voyage dans la lune (L'autre monde ou les états et empires de la lune), ed. Maurice Laugaa (Paris, 1970), pp. $3^{1-32}$; Lachèvre, ed., Oeuvres libertines, I.6. The translation is my own, using Strachan as a base. 


\section{6 - The Discourse of Modernism}

The irony of the terms "vision," "fiction," "chimera," and "madness" ("folie") in the published version draws the reader's attention to the very writing of the novel before him; it emphasizes that what is in question is the very process of discovering thinking and then writing down that thinking. For the textual on ("on nommera") these terms refer to an idea (that the moon is a world) whose falsity is opposed to the truth of those others which preceded it and which are the mythologies of fixed systems. For the narrator, on the contrary, the idea suggested by these terms signifies a possibility of truth, an attempt to remove from the moment of observation all that is not essential to it (I see the moon; the moon looks like what we may suppose the world to look like if we could view it from an analogous vantage point), and to relate that observation to some testable hypothesis (since they look alike, perhaps moon and earth are alike). The ironic commentary will be taken further yet, for the narrator will imply that his first journey is the result of a dream, and even perhaps that it is a dream: "In order to make an end of it, I shut myself away in a comparatively isolated country house where, having gratified my daydreams with some practical measures appropriate to my design, this is how I gave myself to the sky" (F 13; E 5 , my italics).

"Fiction," "madness," "dream" are simply the means that permit the undertaking of a voyage which the narrator intends will terminate in the real and true knowledge of a verified hypothesis concerning the factual world. "Fiction" it is, in the sense that Bacon's or Galileo's or Descartes's invention of a new discourse is also a fiction. Not for nothing does the last of these refer to Le monde as a fable at the outset, only to conclude that it corresponds precisely to the real world. "Madness" it is, because the use of any discourse that is unfamiliar will necessarily be so classified by those whose familiarity is with another. "Dream" it certainly is, if by that one wishes to mark the fulfillment of a desire. What these terms indicate above all is that the discourse is a new invention (fiction), that it is different (madness), that it seeks a particular goal (dream).

In Cyrano's novels, the voyage will always, as in this first experimental sequence, mean a 'passage' through an accumulation of images (here, the mythologies) that will have to be discarded before the goal can be achieved. We have seen how this can be done: by making experience literate. This, it seems to me, is the final implication we can draw from the aside to the reader: the fact that this is a writing. And this is evidently reinforced by the very event which inspired the aside: reading Cardano's written autobiography. Knowl- 
edge progresses, as we have seen Bacon affirm, only when writing makes order and clarity possible, when writing performs the exclusion of superfluities, when it-and it alone-makes possible a legitimate experimental follow-up.

The first two elements of the sequence, observation and discussion leading to hypothesis, are now followed by the third: the experiment to test the hypothesis. In the present case it consists of the narrator's first attempt to fly, achieved by binding dew-filled flasks around himself. To be sure, to the extent that it does not succeed in taking him to the moon this flight is a failure, yet it does respond partially to the hypothesis. Because his ascent and descent are supposedly vertical and because he nonetheless returns to earth not in France but in New France ( $\mathrm{F}_{15} ; \mathrm{E}_{7}$ ), he believes he has successfully demonstrated that the earth turns on its axis. Like the possible similarity of the earth and moon, this is one of the consequences of the heliocentric hypothesis (which will be the matter of the second experimental sequence). Knowledge has therefore been advanced by his experiment, while his own particular hypothesis receives a resounding boost, even though the particular form of this result is more or less 'accidental.' Still, Bacon's method covers this eventuality as well: "in the whole collection of this history of arts it is especially to be observed and constantly borne in mind that not only those experiments in each art which serve the purpose of the art itself are to be received, but likewise those which turn up anyhow by the way." 10

Here, then, the fourth element in the sequence has been supplied: the full or partial verification of the hypothesis. This will in turn be bound directly to a new observation. It will even overlap with it. The sequence remains in that way entirely open-ended, leading immediately - and always-into a following sequence. Before showing how this occurs in Cyrano's novel, however, it might be as well to make an aside of my own, to suggest that the system which is becoming the structure composing the novel is not limited to what we have found in Bacon.

For this structure, not only in the symbolism of the first element of this first sequence (the observation of the moon) but also in the precision of the sequence of elements, reflects very closely what I have been suggesting is also the Galilean experimental method. This begins with what may be called an intuition of truth following upon

10. Francis Bacon, Description of a Natural and Experimental History (aphorism V), in The Works, ed. James Spedding, Robert Leslie Ellis, and Douglas Denon Heath, 15 vols. (Boston, 1861-64), VIII.364. 
the isolation of a given phenomenon which it is then necessary to resolve into elements capable of mathematization. From these it would be possible to deduce, by demonstration, certain generalizations which themselves were taken as a matter of purely mathematical calculation. These two stages correspond, of course, to the first two elements-observations and discussion leading to hypothesis-that we have found formally in Bacon and 'performatively' in Cyrano, though it is only to be expected that the emphasis on mathematics would be altered in them to an emphasis on the elaboration of 'ordinary' discourse.

In Galileo, the exactness of the generalizations which have been elaborated will now be illustrated by "works," by experiments. In the case of the Italian scientist we cannot really speak of a 'testing' because in his view the rigor of the mathematical demonstration dispenses with the need for practical proof. " Nevertheless, even for Galileo experiment leads to a public verification of the hypothesis (generalization). Thus the sequence is the same in Galileo and Bacon, whatever may be its implications for the scientist or philosopher making use of it. In Cyrano, and in the novel in general from now on, these implications will be incorporated in the very structure of its composition.

In the novel, it is probably needless to say, such structure needs disinterring. Still, it is worthy of note in passing, because we are after all speaking of what seems to occur in the 'literary' text, that this 'experimental' sequence will become systematically 'visible' much later as the structure of the detective novel. According to Claude Brémond's analysis of the genre, for example, the detective novel is composed of three basic sequences: the statement of the problem, the investigation, the clearing-up of the mystery. The investigation itself is divided into a further sequence, though it might be clearer if one admitted that the first and last elements in that investigative sequence in fact correspond to the moments of statement and clearing up. That admitted, the investigative sequence is precisely that at which we have been looking: examination of observed facts, elaboration of hypothesis, experimentation, verification of hypothesis. ${ }^{12}$

Almost contemporaneously with Poe's invention of the genre of the detective novel in just these terms, certain 'serious' novelists were

11. For this résumé of the Galilean method I am indebted to Edwin Arthur Burtt, The Metaphysical Foundations of Modern Physical Science (Garden City, N.Y., 1954), p. 81. See also my "Espaces de la pensée discursive: Le cas Galilée et la science classique," Revue de synthèse, no. 85-86 (Jan.-July 1977), pp. 5-47.

12. Claude Brémond, "Le message narratif," Communications, no. 4 (1964), pp. 4-32. 
attempting a similar systematic experimentalism, whose object was the grasping of truths about psychosociological or politicohistorical situations and events: one thinks of Balzac or Dickens, of Tolstoy perhaps or Turgenev, above all of Zola. In the 'serious' novel such a visibility of the experimental system cannot last for long because the 'truths' will soon sink beneath the accusation that they are "contrived.' One might say that the "responsibility of enunciation" has been readmitted to discourse: and in the neoclassical episteme what could then be called its 'objectivity'? It is therefore symptomatic that on the one hand the detective novel heads speedily into the domain of what is now being called 'paraliterature,' where few serious questions are asked of the material of fiction, while on the other such novelists as Stendhal or Flaubert, Dostoevsky or James, appear to be heading elsewhere-toward Proust or Joyce and beyond. The names of Maxwell and Marx, of Peirce and Frege, mentioned already in connection with this new 'crisis,' may be recalled here as well.

It may be that the 'openness' (to use Umberto Eco's term) of such texts as are represented by the last novelists named was not possible until what had become a structure in the seventeenth century had once again been avowed as a system, a visible discursive means of grasping and situating the world of phenomena and of organizing all the objects of our knowledge. It may be that there could be no place for any new class of discourse until the analytico-referential proved to be nothing but a particular form taken by human ordering, and was therefore no longer privileged as the only possible place of truth. It could no longer be the dominant discursive class once this had been made clear, since the introduction of such 'discursive relativism' assumes one is already 'outside' the discourse thus relativized. My Chapter 12 will argue at greater length that we now find ourselves, indeed, at the nether end of the development of the analytico-referential. Other kinds of discourse seek to accompany, if not to displace, it. Yet it remains present and in use. Analyticoreferential discourse has controlled the forms of Western knowledge (and action) from the period we are discussing down to the present day. Not to seek to understand its operation in all types of discourse, then, is to cripple the development of other discourses (of other "knowledge").

Cyrano marks a point at the other end of this time scale, the moment when the experimental order is becoming dominant, and the first sequence of the Voyage dans la lune is a kind of general methodological introduction. It is not only that, however, for it is also where the familiar discourse of patterning is dismantled, the 
only remains being the bits and pieces we have seen dismissed by the narrator as "ingenious fancies." I have further suggested, and the matter will be dealt with at greater length in Chapter 8, that the mythological elements that do remain will themselves be adjusted to the experimental order (which implies that Bachelard's notion of a prescientific mind, recognizable essentially by its use of myth, is far too simplistic).

The experimental structure, it is apparent, reveals itself as a succession of sequences that can be given no foreseeable term: they could come to an end only when the last bit of true knowledge had been found. But no one inside the discursive space in question could know when that goal had been achieved. Indeed, the assumption of having arrived at that point would mean that a different space was now occupied: a space in which such terms as 'knowledge' and 'truth' would be defined within a quite different set of elements and discursive 'assumptions.' The end of the experimental series, then, would be, not complete knowledge, but silence. Cyrano does not shy away from this consequence, as we will see in Chapter 9 .

The second sequence overlaps with the first and begins as the other comes to an 'end.' The experimental flight with the dew-filled bottles leads straight into another observation or, rather, series of observations. The first of these concerns once again celestial bodies in their relation with the earth: "I perceived that the sun was now at its highest point from the horizon, and that it was midday" (F 13-14; $\mathrm{E}$ 5). It is also at this point that the first tentative evidence of the partial verification of the hypothesis is presented: "it seemed to me that, having gone straight up into the air, I should have come down in the place I had left from" ( $\left.\mathrm{F} 14_{4} ; \mathrm{E}_{5}\right)$. As in the first sequence, the observations are multiple and reciprocal. In the first, it was a question of the entire company looking at the moon and of the narrator's idea that someone on the moon might be looking back at them; here the narrator is himself surrounded by men: "j’aperçus," "je me vis entouré," "qu'ils eussent jamais vu," "ils voyaient," "à leur vue." Indeed, the concept and activity of seeing takes over the entire situation: "un moment les vit" (F 14).

The second element, as before, is the attempt to seize the observed phenomenon in a first explanation: here occurs the first material image, the image to which Bachelard has given the name "obstacle." It is this moment in this second stage of the sequence that Galileo himself sets aside as useless, by means of the character Simplicio, in the Two Chief World Systems. In the Lune, the narrator uses many of the same techniques. As a consequence there will be less emphasis on 
the first obstacle hereafter, with the result that the role played by discourse in the knowledge of phenomena will also be less emphasized, as though the act of enunciation itself were unimportant. This consequence is yet to come, however, and for the moment the second stage of the sequence remains highly verbalized.

The narrator now turns to one of the "stark naked men" who have met him and attempts to find out where he is. He is unable to understand the reply: "He mumbled between his teeth for a long time but I did not notice that he was articulating anything and took his talk [langage] for the husky babbling of a mute" ( $\mathrm{F}_{15}$; E 6). This same lack of comprehension is in evidence between himself and the soldiers who come for him immediately afterward. Only after the narrator has met the Viceroy (called "M. de Montmagny" in the Paris manuscript-as in reality) will the further perfecting of his hypothesis occur.

It is as though the immediate "flying-off" to generalization in the terms of a familiar discursive class had been replaced by a kind of suspension of belief which will allow the new discourse to have its say, as though there were now a space of ignorance waiting to be appropriately filled. Little by little that filling will be achieved in conversations with the Viceroy and in response to the latter's questions and proposals. The perfecting of the hypothesis is based on two kinds of evidence now, and the narrator's choice is significant: (1) the experiment of flight that he has already performed, and (2) the arguments advanced by Galileo himself in order to show the 'relativity' of the human mind. Indeed, one might suggest that the form of the discussions between the Viceroy and the narrator echoes that of the Two Chief World Systems, the former playing Sagredo to the latter's Salviati. We even have a Simplicio represented by the Jesuits who take the narrator for a "sorcerer" $(\mathrm{F} 16 ; \mathrm{E} 7)$ and the Father who, dismissing Copernicus, is said to have suggested that the turning of the earth is due to the movements of the damned in Hell who climb around inside to escape the flames $\left(\mathrm{F}_{1} 8 \text {; } \mathrm{E} 9\right)^{.13}$

In the same way the narrator, following Galileo (and others), emphasizes how ridiculous it is to believe that the sun is placed in the sky merely to serve mankind:

For it would be as ridiculous to believe that this great luminous body revolved round a speck which is useless to it, as to imagine when we see

13. See Galileo, "Letter to the Grand Duchess Christina," in Stillman Drake, ed., Discoveries and Opinions of Galileo (Garden City, N.Y., 1957). Galileo notes here his admiration for Copernicus, who never, he writes, confuses mechanistic and religious arguments. 
a roast lark, that the hearth has been revolved about it in order to cook it. Otherwise, if the sun had to perform this task, it would seem as if the medicine needed the sick man, the strong should yield to the weak, the great serve the small and, instead of a ship sailing along the shores of a province the province would have to be navigated round the ship. $[\mathrm{F}$ $17 ; \mathrm{E} 8]^{14}$

From Vergil to Oresme and Cusanus, from Galileo to Cyrano, from Copernicus to Pascal, from Bernier to Fontenelle, the ship/earth image had a fortune all its own. The narrator himself uses it here a second time to dismiss just this sort of hasty generalizations, toofamiliar ways of speech, illiterate experience: "Sir, I replied to him, the majority of men, who only judge things by their senses, have allowed themselves to be persuaded by their eyes, and just as the man on board a ship which hugs the coastline believes that he is motionless and the shore is moving, so have men, revolving with the earth about the sky, believed that it was the sky itself which revolved about them" (F 19; E 10). ${ }^{15}$ Another dispute recalled by the narrator had become virtually the symbol of the struggle between the old and the new, between biblical exegesis and natural philosophy: the debate around "Joshua's sun"; it is repeatedly in the same sources. ${ }^{16}$

14. And a little later: "No, no, if this visible god lights man's way it is by accident, as the King's torch accidentally gives light to the passing street-porter" (F 19; E 10). Most of the arguments and images concerning the 'relativity' of the human mind are to be found in the Third Day of Galileo's Dialogue Concerning the Two Chief World SystemsPtolemaic and Copernican, tr. Stillman Drake, 2d ed. (Berkeley and Los Angeles, 1970), esp. pp. $367-68$. They are to be found also in Campanella's Apologia pro Galileo (Frankfurt, 1622), and in John Wilkins's A Discovery of a New World. . (London, 1638), among many other places.

15. See, e.g., Galileo, "Letter to the Grand Duchess Christina," pp. 170, 200-202; Two Chief World Systems (Second Day), pp. $115 \mathrm{ff}$., 255. Diodati, translator into Latin of some of Galileo's material, was a close friend not only of Galileo himself but of Gassendi as well, in whose learned circle Cyrano himself moved (not to mention, among others, Thomas Hobbes). Many of the arguments used here by Cyranó's narrator had of course become commonplace by this time and no particular acquaintance was necessary in order to pick them up. Gassendi's own works are full of thema fact to which the Viceroy refers ("I have read several books by Gassendi on this subject," F 18; E 9). The fact remains that the terms of the critique recalled by the narrator are those constantly used by Galileo himself to buttress his experimental system. Still, what is of interest here is not the search for sources but the increasing familiarity of a discourse that had been new for Galileo and Bacon. On the particular image of ship:shore::earth:sun, see Erica Harth, Cyrano de Bergerac and the Polemics of Modernity (New York, 1970), p. 144 .

16. E.g., most notably, in the "Letter to the Grand Duchess Christina." Foscarini, one of Galileo's less cautious supporters, wrote an entire volume around the subject: his volume was placed on the Index soon after its publication. Says the narrator of the Lune: "I was insolent enough to imagine God had favoured my daring by once more nailing the sun to the heavens" ( $\left.\mathrm{F}_{14} ; \mathrm{E}_{5}\right)$. 
The narrator extends his hypothesis in a perfectly coherent way, and one which is again susceptible (in time) of experimental proof. Beginning the second sequence with a partial verification of one of the implicit conditions of his hypothesis (that the earth turns upon its axis) achieved by the first flight, he has gone on to affirm that the earth turns about the sun, that therefore the sun is a star like any other, and that one may therefore conclude with the hypothesis that there is an infinity of habitable worlds (F 19-20; E 10). In all this he is merely repeating the more audacious hypotheses of those who were carried away by the new discoveries, and it might seem that we are here confronted with those same overhasty generalizations of which we have seen Bacon so critical. However, the point of these hypotheses in the novel is that they set forth an experimental program-of which only certain parts will have actually been 'accomplished' by the 'end' of the Voyage au soleil.

Clearly the hypothesis has been considerably broadened and extended, and the trip to the moon will now serve to verify only a part of a far more ambitious program. The scheme could only be formulated 'legitimately' after the first experiment had proved partially successful. In this the novel is following exactly the precepts laid down by Bacon and carried out by Galileo. For this reason it is rather striking that the narrator should stress as a third stage in this sequence an experiment that recalls the point of departure both of the novel and, in the sense stressed at the very outset of this volume, of the order of analytico-referential discourse itself. He suggests that just as he and his companions had watched the moon, so the Viceroy should emulate Galileo's second series of telescopic experiments and study sunspots: "if ever I have the honour of seeing you in France, I will have you observe by means of a most excellent spyglass, how certain obscurities which look like spots from here are worlds in formation" (F 22; E 12). At this point discourse as such ceases, as one might expect: "My eyes were closing as I finished this speech and the Viceroy was obliged to leave me" (F 22; E 12).

It is nevertheless not this experiment which is now carried out (though the hypothesis behind it is 'verified' on the flight to the sun in the novel's sequel). Rather, it is almost as though we ourselves traveled up the telescope: from this sleep we pass directly into the next experience of flight. This is carried out (accidentally) by means of rockets and, when these fail, by the suction effect of the moon on the animal marrow with which the narrator had smothered wounds received in a fall when testing his flying machine. Clearly this is the 
third element of the second sequence. And it immediately verifies his initial hypothesis. For he lands on the moon in the midst of the luxurious vegetation of the "earthly paradise." Luckily for him he lands in the "tree of life" and some of the juice of its fruit runs into his mouth; otherwise, as he observes, he might not have survived ( $\mathrm{F}$ 25 ; E 15). A completely new knowledge is now possible, in a new world; a different world, certainly, but a world nonetheless.

That this knowledge is possible is, then, the result of the experimental verification of an hypothesis "educed," as Bacon calls it, from particulars, and as the result of posing "judicious questions." In the second stage of the two sequences we have so far examined, the narrator gave pride of place to discourse as the means of organizing reality and producing works. From now on this will no longer be the case.

Knowledge will increasingly be achieved when-and becausediscursive awareness disappears, for, far from being a conscious organizing principle, it has been made 'transparent.' Little by little, as I have indicated, the evidence of the role of discourse as making possible and organizing all knowledge is being obliterated, as though the act and responsibility of enunciation were themselves being occulted. On the contrary, the use of language per se will be proffered as the chief obstacle to true knowledge and true communication, and it is in those terms that the philosophical discussion of language will henceforth take place (and not only in the novel), up to and including, for example, Saussure. As we will see in Chapter 9, the treatment of language in Cyrano's two Voyages is increasingly in the form of concern over an obstacle to experimental knowledge. This is a principal mark of the passage to domination: the disappearance of the "conscious' discursive ordering of what is spoken of.

Two full sequences have now been completed in the Lune.

I. First sequence

1. View of the moon

2. Discussion and hypothesis concerning what it is or is like

3. Flight to "New France"

4. The earth turns (one element of the new cosmology verified)

II. Second sequence

1. View of the sun and of New France

2. Discussion and further hypothesis concerning the world, the solar system, and the universe

3. Flight to the moon

4. The moon is a world (another element in the new cosmology and the narrator's initial hypothesis verified) 
As expected, we are taken right away into the next sequence. That the moon is a world has actually been only partly verified, for the narrator's landing in the "paradis terrestre" would appear to provide equal evidence for the suggestion of his companion who sought to fit the moon into the order of a Christian myth. The third sequence, while following the same order as the first two, appears to seek falsification rather than verification. In this way two aims are to be accomplished. First, one alternative general theory of 'true knowledge' will be excluded (the Christian); second, the experimental 'theory' will be reinforced in accordance with the Baconian dictum concerning the exclusion of contradictory instances.

In the earthly paradise, then, the first stage of the sequence becomes unreliable. The narrator looks around, but is not able to trust his eyes: "stones were neither hard nor uneven ["except to the eyes," adds the Paris manuscript] and they were careful to soften themselves when one walked on them" $\left(F_{25}\right.$; E 16). The senses no longer support one another; rather they dispute each other's evidence-in direct contradiction to the atomistic explanation of the

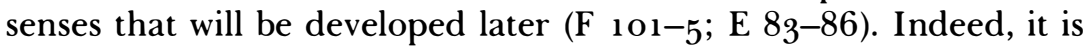
evident that if the senses could not be trusted experimental knowledge of any kind whatsoever would be beyond human powers. Since the first two experimental sequences have already been shown to work, we are at liberty to doubt the case where experimental proof would be axiomatically impossible: the case, that is, whose first axiom would be that the senses cannot be trusted. This would lead us to blind faith: "it is to God that you owe this homage!" cries Elijah (F 28; E 18). That, of course, would be to return to a position of no knowledge at all in any scientific sense.

In the earthly paradise the first stage of observation cannot even give rise to a meaningful second stage. The narrator looks at the enormous trees that appear to grow there: "Letting my eyes wander from the roots to the top, and then fall from the summit to the foot, I began to wonder [je doutais] whether the ground supported them or if they did not themselves carry the ground suspended from their roots" (F 26 ; E16). This observation, or anti-observation, can lead only to attempts at description. Whereas in the first two sequences observation gives rise quite naturally to the development of a hypothesis, here it cannot because it is itself far too uncertain. Even 'simple' description, unburdened of some firm basis, unladen of any theory whatever, proves a chimera: "One would even take this plain for an ocean, since it is like a sea which offers no shore, so that my eye, terrified at having run so far without discovering the edge quickly sent my 


\section{6 - The Discourse of Modernism}

thought after it; and my thought unwilling to believe it was the end of the world, wanted to persuade itself that the charms of the place had perhaps compelled heaven to join on to the earth" (F $27 ; \mathrm{E} 17){ }^{17}$

Preciosity is itself, perhaps, no other than a different discursive means of ordering reality. But why is it necessary to bring in such a passage here (and what is quoted is only a small part of a very long passage of description in the same vein)? The negatives, the conditional, the subjunctive, verbs of doubting and of fearing, all accumulate to reveal the failure of description and observation. The mind has recourse immediately to generalizations. It goes with all speed from failed observation ("mon oeil épouvanté") to overweening imagination and reasoning by analogy-and tautological analogies at that: the plain was like an ocean because it was like a sea; because it was a sea with no visible edges it was like the end of the world, and so on. What is being presented here, in burlesque form, are the worst elements of the very kind of thinking that the narrator is seeking to replace. And things go from bad to worse.

It is at this point that the narrator comes across Elijah. The prophet proceeds to translate Genesis into a series of voyages between the earth and the moon ( $\mathrm{F} 28-40_{2}$ E $\left.18-28\right)$. Needless to say, all this fails the first test of the experimental discourse: it is untestable by means of reference to particulars-though the narrator does meet Enoch, one of those who is supposed to have made the trip. The narrator dismisses these tales first with obscenity (F $36 ; \mathrm{E} 25)$ and then with blasphemy ( $\mathrm{F}$ 39-40; E 28). Not only does the place itself give rise to contradictions, quite apart from its being the "earthly paradise" on the moon, ${ }^{18}$ but Elijah, who now affirms that he has the "perfect philosophy" of the old Adam (F 33; E 22), is given to making claims whose only 'proof' is their own assertion (that the narrator's blasphemy, for example, would not go "unpunished if the AllWise God did not wish to leave you to the nations as a famous example of His mercy," F 40; E 28), and statements that are contradicted by experience. In this way he asserts that eating the skin of the

17. "On prendrait même cette prairie pour un océan, à cause qu'elle est comme une mer qui n'offre point de rivage, en sorte que mon oeil épouvanté d'avoir couru si loin sans découvrir le bord y envoyait vitement ma pensée; et ma pensée doutant que ce fût l'extrémité du monde, se voulait persuader que des lieux si charmants avaient peut-être forcé le ciel de se joindre à la terre" (my italics).

18. When he lands in paradise the narrator's hunger disappears completely because of the place; however only a short while later he complains of being famished, and twice at that: "if I had been in a state to die of anything else but hunger," "my hunger tormented me so violently" ( $\mathrm{F} 4 \mathrm{O} ; \mathrm{E} 28,29)$. No doubt this can be explained on the grounds that he first ate the tree of life, while later he is to be punished by Elijah. But this is simply one hesitation or contradiction among several. 
fruit of the Tree of Knowledge will lead to complete ignorance ( $F$ $36-37$; E 25), but when the narrator does so later on it does nothing of the kind. For this contradiction the narrator tries to find some explanation, but it will remain as unverifiable as Elijah's original claim ("I have surmised," F 41; E 29).

The narrator eventually passes out of the earthly paradise exactly as though he were leaving some kind of dream: "a thick cloud enveloped my mind: I no longer saw anyone beside me, and my eyes could not discover a single trace of the road I had taken anywhere on this side of the horizon, but for all that, I did not fail to remember everything that had happened to me" (F 41 ; E 29). ${ }^{19}$ It is as though a further journey (for he now finds himself in the midst of an unknown country) had demonstrated the meaningless-indeed burlesque in the telling-nature of whatever kind of knowing might derive from the Christian mythology.

At the same time, this experiment further confirms the original hypothesis of the moon as a world. All he has learned from the earthly paradise is the evidence provided by his first landing there and finding things growing just as on earth. All the rest is a mockery of the knowledge he is seeking. Now the learning process can continue once again: the narrator shortly sees people coming toward him and will soon be taken to his first lunar town ( $\mathrm{F}_{42}$; E 29). We may call this an 'experiment' because, as in New Atlantis, the 'journey' and the 'experiment' have become virtually synonymous. In the Voyage au soleil, indeed, they become so quite explicitly. Thus the "atomic tree" in its human form tells Dyrcona that his people spend their time journeying about in order to achieve "a certain science of what is" ("une science certaine de ce qui est," F 189; E 160), and Campanella informs him that he travels for just the same reason $(\mathrm{F}$ 240 ff.; E 205 ff.). Earlier in the same novel Dyrcona will beseech one of the talking trees to "deign to enlighten someone who had only risked the perils of so great a journey in order to learn" ( $F$ 225-26; E 192).

As before, the journey both concludes and begins a series: "In vain I cast my eyes about me and scrutinized the landscape" ( $\mathrm{F}_{4} 1$; E 29). The narrator recommences his observation, at the same time proving two previous hypotheses: (1) that the Christian myth is a

19. "Une épaisse nuée tomba sur mon âme; je ne vis plus personne auprès de moi, et mes yeux ne reconnurent en tout l'hémisphère une seule trace du chemin que j'avais fait, et avec tout cela je ne laissais pas de me souvenir de tout ce qui m'était arrivé." No doubt one could argue that this "passage" corresponds exactly to his blasphemous remark concerning the ascension of St. John the Evangelist, and that it therefore "bears out" the Christian myth. 


\section{8 - The Discourse of Modernism}

fantasy so far as the winning of knowledge is concerned ( $\left.\mathrm{F}_{11} ; \mathrm{E}_{3}\right)$, and (2) that the moon is like the earth: for clearly there are several different countries, of which some appear to be unknown to others. He also discovers that the moon is occupied by people who "had bodies and faces like ours" ("avaient la taille et la figure comme nous") but who walk on all fours ( $\mathrm{F} 41$; E 29).

From now on, indeed, it is no longer necessary to state any hypothesis: all experiments and experience from now on in the novel will set out to fill in the particulars of the general hypothesis that the moon is like the earth. In a sense 'mere' experience is now just as useful as experiment, for it henceforth occurs in the context of the initial hypotheses; it is now always literate; it is "theory-laden."

Nevertheless, the reader is presented at the same time with what amounts to a refutation of the other mythologies. If the earthly paradise is revealed in its essential uncertainty and aimlessness, then the first part of the narrator's stay with the lunarians is virtually a demonstration of the flaws in any way of knowing other than through experience. The lunarians are at first likened to "sirens, fauns, and satyrs" (F 41; E 29), and we discover little by little that they suffer from all the errors that the experimentalists are trying to overcome. The exception to this rule is the "demon of Socrates" who sets out to teach the narrator, just as he says he had taught Socrates, Epaminondas, Cato, Cardano, Agrippa, Campanella (especially), La Mothe Le Vayer, Gassendi, and the rest (F 43-44; E 31-33). The demon explains that he is a native of the sun and that he is here because the people of the moon "are lovers of truth. There is not a pedant to be seen. Philosophers only permit themselves to be persuaded by reason, and neither the authority of a scholar nor that of the majority can outweigh the opinion of a thresher on a farm, provided he reason with sufficient force. In this country, briefly, only sophists and rhetoricians are considered to be mad" (F $46 ; \mathrm{E}$ 34).

Such is the demon's ideal. It is not generally borne out, however, by the narrator's experience on the moon, which tends to demonstrate rather the prevalence of a more common attitude: "There is a common herd here as there is there [on earth], who cannot tolerate the thought of anything to which it is not accustomed" (F 43; E 31). This remark corresponds to Gonzales's later criticism to the effect that on earth "whatever fine things you may say, if they are against the principles of the doctors of the cloth, you are an idiot, a madman, and something more besides" (F $58 ; \mathrm{E}_{45}$ ). Like the narrator, the inquisitors of the moon reject the authority of an Aristotle (F 69; 
E 55); but when the narrator is on trial for having suggested that he is human, that their "moon" is a world, and so on (F 66-70, 74-79; E $53-55,59-62)$, they show themselves every bit as closed to unfamiliar notions as had his companions on the road to Paris, as will Dyrcona's accusers at the beginning of the Soleil (F 132-43; E 109-19) and the birds later on in the same novel (F 201-15; E 170-82).

When they do not understand something the lunar populace, like the narrator himself at the end of the first experimental sequence, close their ears: those who hear him and Socrates's demon conversing together in Greek take that language "for inarticulate grunting" ("un grognement non articulé," F 48; E 36 ). The narrator himself has learned from his experience and rapidly gets to know his hosts' languages ( $\mathrm{F}_{77}$; E 54)-with disastrous results. For it leads to just those arguments concerning reason and instinct, animal nature and human, the privilege of the human world over the other realms, which are to place him before the lunarian inquisition.

In fact the narrator learns relatively little from the lunar people, with the exception of some information about their customs from a girl at the court who takes a liking to him. What he learns he learns from Gonzales, another representative of the new experimentalism; from Socrates' demon, who argues from his own experience but more from what he can demonstrate on material present to the senses; and from the "host's son" in the latter half of the Lune, whose status is dubious since he may be the Antichrist!

In this way the narrator makes acquaintance with an atomistic theory of all matter ( $F_{5}^{8-63}, 99-10_{5}$; E 45-49, 80-86), with the consequent unity of matter and "spirit" (F 63-66; E 49-52), with the notions of the infinity of worlds (F 92-94; E 75-77) and the eternity of the universe ( $\mathrm{F} 75,95 ; \mathrm{E} 59,77)$. All this, deriving from an atomistic theory, provides in turn an explanation of the reason why the senses, though fallible in man, are nevertheless adequate to a 'comprehension' of material things: the senses and all material things are merely different configurations of the same basic atomic forms (F 102-5; E 85-86).

Certainly the demonstration of much of this is peculiar, to say the least. But that is not the point. The point is that demonstrations are always made by means of material particulars. Some of these will be carried to further fruition in the Soleil. There it is demonstrated that the earth turns ( $\left.\mathrm{F}_{1} 66-67 ; \mathrm{E}_{140}-41\right)$; the hypothesis of the infinity of worlds, if not proved, is at least provided with the strong evidence of the "several earths like ours" which Dyrcona leaves to right and

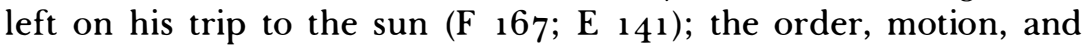


physical composition of the planets is suggested by the waxing and waning of Venus and Mercury (F 167; E 141); that sunspots are worlds being created is 'proved' by his landing upon one ( $\mathrm{F}{ }_{1} 69$; $\mathrm{E}$ 143); atomism is verified by the well-known episode of the tree of precious metals and stones which dances itself into a vast number of people, then into one person, and finally into a flock of birds which flies away (F 184-97; E 156-67).

Indeed, Dyrcona's initial landing on the sun may be viewed as a specific correction of the failure of the earthly paradise. When he finds himself on the "plains of day" his immediate feeling is that they are not solid:

My very body was bewildered and sought the support of my eyes, but since this transparent land through which they penetrated could not hold them up my instinct became master of my thought in spite of myself and drew it towards the hollow depths of a bottomless light. However, my reason gradually disabused my instinct; I left firm and untrembling tracks upon the plain, and I measured my paces so proudly that if men could have seen me from their world they would have taken me for the great god who walks upon the clouds. [F 183; E 155]

It might be suitable to conclude this chapter on such a note: the experimental scientist as the godlike bringer of knowledge, the new Prometheus. That aspect of the Lune is indeed the subject of the next chapter. However, in addition to demonstrating how to verify hypotheses by experiment, how to use material particulars so as to provide at least evidence for, and not seldom proof of, a given hypothesis, ${ }^{20}$ another aspect of this novel is particularly revealing: it appears to include certain elements of a theory of probability. Such a theory, of course, is tied in with the whole matter of experiment and evidence in the sense of which I have just been speaking. It is an essential witness to the power of analytico-referential discourse. On occasion it becomes an explicit concern of the novel, where its presence is profoundly significant.

Ian Hacking has placed the emergence of a mathematical theory of probability in a broad "conceptual space" (not, that is to say, as it may have appeared as an isolated instance in the work of a Cardano) squarely in the decade around 166o. The key figures are Pascal and the authors of the Port-Royal Logic, though Hacking quotes a pas-

20. The existence of the different worlds the narrator passes on his journey is evidence for the theory of the infinity of worlds; that he actually sees the lands of the earth passing around its surface is proof that the earth turns. 
sage from Hobbes in which he spots the first emergence of probability "in all but name," and he emphasizes at the same time the importance of Gassendi in this matter. ${ }^{21}$ It is a matter of historical record that from 1641 on Cyrano was very closely associated with Gassendi and the circles in which Hobbes was a familiar. Where Cyrano may have 'obtained' such elements of probability as occur in the novel is, I feel, of no greater interest than may be the 'precise' source of the Galilean elements which have been mentioned. For the point is-and Hacking makes it repeatedly and well-that the emergence of the modern theory of probability is directly tied ('discursively,' as I have been saying here) to the developments we have been considering. It is, that is to say, an integral part of this new class of discourse, and an exemplary case of its use of abstract systems as true descriptions of the concrete.

"Probability," writes Hacking at the very outset of his work on the subject, "has two aspects. It is connected with the degree of belief warranted by evidence, and it is connected with the tendency, displayed by some chance devices, to produce stable relative frequencies." ${ }^{22}$ Both of these aspects appear explicitly in Cyrano's first novel, though evidently not in precise mathematical terms.

As to the second, the narrator recounts, toward the end of the Lune, how his host's son likens the atoms of nature to just such a chance device: he points out how, when we play with three dice, the possible permutations are such that any given configuration of the dice considered singly may appear to require explanation in terms of law. He observes that this is nonsense and that what is significant is the totality of possible permutations:

When you throw three dice upon a table and a triple two comes up, or three, four, five, or two sixes and a one, you will say: "Oh, what a miracle! The same number has come up on all the dice, although so many numbers could have done!" "Oh, what a miracle! Three consecutive numbers have come up!" "Oh, what a miracle! Just two sixes have come up and the opposite side of the other six!"

But no, I am sure that being a man of intelligence, you will never make such exclamations, since the numbers on the dice are limited and it is impossible for one of them not to come up. [F 10o; E 81-82]

21. Ian Hacking, The Emergence of Probability, pp. 48, 46-47. The work of Hobbes in question is Humane Nature, or the Fundamental Elements of Policie (London, 1650), IV.10; probably written around 1640 .

22. Hacking, Emergence, p. 1. He goes on to say that "neither of these aspects was self-consciously and deliberately apprehended by any substantial body of thinkers before the time of Pascal." 


\section{2 - The Discourse of Modernism}

Problems of chance in dicing, as Hacking observes, had been around for some time and remained a matter of lively, if playful, interest to mathematicians; more significant is the connection that is then made with the atoms of nature. Hacking notes a certain passage in the Sanskrit Mahábarata (c. 400 A.D.) in which a similar connection is made between dicing and the estimation of the number of leaves and fruit found on the branches of a tree, and he remarks on "the degree of sophistication" that is implied in the making of such a connection. It is clearly not at all evident that a calculus of probabilities applicable to problems in dicing can be transferred to particulars in nature. That is why Hacking adds: "Even after the European invention of probability around 1600 it took some time before any substantial body of people could comprehend that decisive connection." 23

The manuscript of Cyrano's novel was circulating from around 1649-50 (though the passage in question was cut by Le Bret when he published the novel in 1657). Madeleine Alcover argues that while the terminus ad quem of the completed Lune was certainly $165^{\circ}$, it seems probable that the novel was fairly well along as early as $1642{ }^{24}$ The significance of these dates is not merely anecdotal. The applicability of an abstract calculus of probabilities to concrete phenomena was in the air, a clearly integral part of the development of the new analytico-referential discourse.

Certainly, nothing here indicates the possibility of a mathematical law capable of describing the relative frequency of the occurrence of each permutation. Yet when the connection is made with atoms in nature there do appear some hints of ideas moving in the same space. For the host's son proceeds to explain the increasing infrequency of increasingly complex configurations of atoms on the grounds of the increasing number of possible permutations, so that the 'right' one (for the creation of a human, for example) turns up only rarely, whereas simple configurations turn up very frequently because the possible permutations are so much fewer (F 100-O1; E 82). Thus he explains the bottom-heavy nature of the ladder of creation. What we may think of the argument in itself is a matter of indifference, and it may be that the "probability calculation" gets little beyond common sense. What remains noteworthy is the application of probability to nature.

This is not the only example of probability theory. The other aspect noted by Hacking, the question of warranty for belief, also occurs. Very interestingly it appears in the form of an abbreviated

23. Ibid., p. 7 .

24. Alcover, ed., L'autre monde, pp. xxxv-xl. 
and simplistic version of what is now known as Pascal's wager ${ }^{25} \mathrm{Cy}-$ rano's version retains more than a tinge of the older meaning of probability as authoritative opinion, and many of the limitations Pascal placed on the context of his wager are lacking, ${ }^{26}$ but it is striking that it should occur here in any form at all.

The host's son flatly denies the existence of God. Unlike Pascal, the narrator sets out to offer an attenuated choice between the act of belief and that of disbelief: while it may not be possible to decide to believe, it is possible to decide as to the wisdom of belief. Pascal sets out to bring an agnostic into a state where belief becomes possible; it is not simply a matter of advantage, but one of probable correspondence with a divine reality. The narrator of the Lune seeks to bring an atheist to a state where belief may be seen to be advantageous. Although with less force than Pascal, ${ }^{27}$ the narrator leads up to the wager by deliberately setting aside arguments from probable authority (though such authority tinges the argument about God Himself): "'I will not amuse myself,' I said to him, 'by reciting to you the clear demonstrations by means of which the philosophers have established this, for I should have to repeat all that reasonable men have ever written" (F 122; E 100-O1). The wager itself follows immediately:

I will only ask you what inconvenience you find in believing it, and I am certain you cannot claim a single one. Since it is impossible to derive anything but benefit from it, why do you not convince yourself [que ne vous le persuadez-vous]? For if there is a God, apart from the fact that in not believing this you will be wrong, you will have disobeyed the precept which commands us to believe in Him. While now, even if there is none, you are still no better off than us. [F 122; $\left.E_{101}\right]$

The argument here seems to be that which Hacking analyzes as the argument from dominance. ${ }^{28}$ The choice is between two states of the world (there is no God; there is a Christian God), ${ }^{29}$ and two courses of action (disbelief and belief). Each implies different benefits.

25. For the chronologically minded it is perhaps worth recalling here that Pascal's discussion does not appear in print until 1670 , though a version of it was printed at the end of the Port-Royal Logic in 1662. A form of it will be included in 1690 in Locke's Essay Concerning Human Understanding, II.xxi.72.

26. Emergence, pp. 18-30, 65-69.

27. See, e.g., ibid., p. 71 .

28. Ibid., pp. 64,67 .

29. That the God is the Christian God is, of course, one of the restrictions in Pascal's wager. It may appear unclear here that such is the choice, but as soon as the argument of authority of the word is invoked (the precept which commands us to believe in Him), it is clear that this restriction is intended. Actually the context of the wager in the novel is in any case a discussion about a Christian God, though the way the wager itself is presented lacks some clarity. 
The argument is clear enough: if there is no God then neither belief nor disbelief will make any difference; if there is a God disbelief will bring damnation (the necessary result of disobedience), while belief can bring only "utilité." Since it is obvious that the latter is preferable to the former in the second state, while in the first conditions are precisely even, then the wager in favor of the premise "there is a Christian God" dominates.

Underlying this is the assumption that two different life-styles are at stake. The atheist is able to reply: "Indeed I am better off than you, ... for if there is none, you and I are evenly matched [à deux de $j e u$ ]: but if on the contrary there is one, it will be impossible for me to have offended something which I did not believe existed at all, since in order to sin, one must either know it or wish it" (F 122; E 101). This argument amounts to saying that if there is a God belief will bring salvation (the theme underlying the term "utilité"), but disbelief can bring nothing less because a Christian God could not possibly hold this lack of belief against me, once the premise of the wager is accepted. The atheist then proceeds to embroider at some length on this theme, affirming that damnation because of ignorance would contradict the narrator's premise as regards the nature of a Christian God. On the other hand, if there is no God, then disbelief makes me "better of $f$ than you." This assertion is possible only if disbelief implies that a different life-style follows from it: otherwise it would obviously make no difference at all.

Pascal would presumably be able to answer this objection by affirming that the Word is an integral aspect of the Christian God and that therefore if there is a God the argument of ignorance is automatically invalid. Quite clearly the wager as it appears here is more than a little defective, and bears small comparison with Pascal's logical machine so admirably analyzed by Ian Hacking. Yet, once again, the important point is that the discursive scheme throws up these aspects of probability as an integral part of its space: and Locke will base an entire concept of the human upon them.

The narrator himself finds that he is unable to answer the atheist's arguments except by a "fit of shuddering" in the face of such "ridiculous and diabolical opinions" (F 123; E 102). He is forced back on a burlesque of the Church's response to such positions: the holder of them is the Antichrist and will go to Hell, dragged in the devil's wake-with the narrator clinging to his heels (F 124; E 102-3).

This conclusion reaffirms the ambiguity in the novel. I said earlier that the discourse represented by Elijah had been discredited by that of experimentalism. And yet the narrator, who has previously been 
accused by the Prophet of skirting such blasphemies (F 40; E 28), does get back to earth on the heels of the devil, who does, it would appear, continue on down to Hell inside earth with the host's son (named as the Antichrist). Elijah had said that the narrator would be left alive as an example of God's mercy, and it is according to Christian eschatology that the prophet Elijah is to be one of the witnesses (with Enoch) against the Antichrist at the Day of Judgment.

On the other hand, the narrator escapes condemnation (Elijah's claim being unverifiable), and he does come to a landing in Italy, the country of Galileo, in what amounts to yet one further reminder of the scientist whose abjuration had earlier been parodied: "Such is what the priests deem it good for you to believe!" (F 78; E 62). At the end of the Lune the success of the narrator's return to the very cradle of experimental science seems to indicate the dismissal of both church and the devil, and their replacement by the triumphant narrator, repeating the practice of Galileo, Bacon, and others. Yet the ambiguity is maintained, for the novel concludes on a note of piety which we are free to take as ironic or not, as the fancy suits us.

It is as if the narrator were finally leaving us with a choice of a rather different kind from that expressed in the wager, though the implications are inextricably linked: given that the world exists, does that necessitate the existence of God? Of course, in a sense the very fact of proposing the wager presupposes a negative answer, because it makes the matter of God's existence one of probability, while to be in a position to propose the wager makes the existence of the world axiomatic. This being so, is it possible to propose a way in which the world could exist without God? The answer in the Lune leans toward the affirmative. It is sought in the very terms of probability I have been indicating.

If God did not create the world, whence did it come and how does it "keep going"? The answer provided in the novel assumes first the eternity of the world (an assumption which, like that of the Creation, is neither verifiable nor falsifiable-the world in this case meaning the 'universe'). The novel then goes on to consider whether the evidence is sufficient to permit a nondivine explanation of the existence of such things as different material bodies, motion, the animal senses, intellect, 'soul,' emotion, and so on. This evidence is sought in terms of the random movement of atoms combining with sufficiently stable relative frequencies to account for the recurring existence of these things (Bacon's "letters of the alphabet," his "seeds of things").

In the Lune the answer is perhaps tentative. It may be a novel 


\section{6 - The Discourse of Modernism}

which is also in part 'about' the formation of a discourse. In the Soleil the narrator gathers sufficient further evidence to provide a resounding "yes" for an answer. But by then the question is only partly about the existence and nature of things per se. It has come increasingly to focus on communicating our knowledge of that nature.

At this point it would seem useful to diagram the experimental structure of the Voyage dans la lune that we have been exploring. This will provide a few more details in answer to the problem raised at the end of Chapter 4, where I suggested that by the time of Cyrano's novel the structure (of "thought") that has developed is composed of an open-ended series of experimental sequences beside which no other kind of discursive ordering remains. I use the same diagram as before (see facing page).

As before, the nomenclature of these columns is of no particular importance. What the plan indicates is that any suggestion we may make of a single overall order is precisely the same as that of each sequence taken individually. More significantly still, we will see in the following chapter that this is the case even when we consider the 'material of myth.' It is thus quite different in its ordering from a text like Kepler's Dream. No longer is there an alternative class of discourse available for even a suggestion of use-and thus, too, a Bachelardian 'psychoanalysis' is unacceptable.

It is no doubt the triumph of this order which gives the narrator confidence enough toward the end of the Voyage au soleil, after the rejection through falsification of the other mythologies that we have seen, to undertake the beginnings of a criticism of that 'other' modern method, that of Descartes. This novel has been universally considered an affirmation of Cartesianism, but it certainly contains a criticism of that discourse's most apparent contradictions with the discourse of experimentalism (for, as I have implied, they are in many ways similar).

Campanella informs the narrator that on the sun Descartes is considered the philosopher's philosopher, with a mind so subtle that only the "true and consummate philosopher" can hope to understand his work (F 251; E 214). He finds himself obliged to make this assertion after the narrator has suggested that Descartes's theory of the origin of the universe contradicts his other notion that there can be no vacuum in nature. Since this notion is also contradicted by "geometry" (F 250; E 213), Campanella is reduced to referring the narrator to the Frenchman himself, whom he is later to meet $(\mathrm{F}$ 271-72; E 232).

The Italian then goes on, in a discussion that becomes increasingly 


\begin{tabular}{|c|c|c|c|}
\hline View of moon & $\begin{array}{l}\text { Presentation of } \\
\text { mythologies; } \\
\text { hypothesis that } \\
\text { moon is a world }\end{array}$ & $\begin{array}{l}\text { Flies to "New } \\
\text { France" }\end{array}$ & Earth turns \\
\hline $\begin{array}{l}\text { View of sun and } \\
\text { of New France }\end{array}$ & $\begin{array}{l}\text { Discussion and } \\
\text { hypotheses of } \\
\text { new cosmology }\end{array}$ & Flies to moon & Moon is a world \\
\hline $\begin{array}{l}\text { View of earthly } \\
\text { paradise }\end{array}$ & $\begin{array}{l}\text { Confusing } \\
\text { description }\end{array}$ & $\begin{array}{l}\text { Eats fruit/ } \\
\text { displacement } \\
\text { in space }\end{array}$ & $\begin{array}{l}\text { (1) Christian myth } \\
\text { is useless for } \\
\text { knowledge; (2) } \\
\text { moon is made up } \\
\text { of several lands }\end{array}$ \\
\hline \multirow[t]{4}{*}{$\begin{array}{l}\text { View of moon } \\
\text { people }\end{array}$} & $\begin{array}{l}\text { Necessity for } \\
\text { interpretation }\end{array}$ & $\begin{array}{l}\text { Travels to } \\
\text { lunar town }\end{array}$ & $\begin{array}{l}\text { People live in } \\
\text { society as on } \\
\text { earth }\end{array}$ \\
\hline & $\begin{array}{l}\text { Discussions with } \\
\text { the demon of } \\
\text { Socrates }\end{array}$ & $\begin{array}{l}\text { Travels to } \\
\text { court }\end{array}$ & $\begin{array}{l}\text { Political } \\
\text { institutions are as } \\
\text { on earth }\end{array}$ \\
\hline & $\begin{array}{l}\text { Discussions with } \\
\text { Gonzales; } \\
\text { inquisition }\end{array}$ & $\begin{array}{l}\text { Travels to } \\
\text { house of } \\
\text { demon of } \\
\text { Socrates' pupil }\end{array}$ & $\begin{array}{l}\text { False method is } \\
\text { dismissed; } \\
\text { people think } \\
\text { like those on } \\
\text { earth }\end{array}$ \\
\hline & $\begin{array}{l}\text { Discussions with } \\
\text { host's son, etc., } \\
\text { about atomism, } \\
\text { infinity of } \\
\text { worlds, eternity } \\
\text { of universe, } \\
\text { nature of senses, } \\
\text { existence of } \\
\text { God, etc. }\end{array}$ & $\begin{array}{l}\text { Returns to } \\
\text { earth on heels } \\
\text { of the Anti- } \\
\text { christ borne by } \\
\text { the devil, lands } \\
\text { in Italy }\end{array}$ & [Ambiguous] \\
\hline OBSERVATION & $\begin{array}{c}\text { DISCUSSION } \\
\text { AND } \\
\text { HYPOTHESIS }\end{array}$ & EXPERIMENT & VERIFICATION \\
\hline
\end{tabular}

ironic in tone, to relate how the philosophers on the sun use Descartes's principles in their discussions because they are "certainly so clear, and seem to satisfy everything so well" (F 251; E 214). Unfortunately this clarity is not borne out by example, and what follows ends up in a contradictory confusion:

You will well remember how he says that our understanding is finite. Thus, since matter is infinitely divisible, one cannot doubt that this is 


\section{8 . The Discourse of Modernism}

one of those things that our understanding can neither understand nor imagine, and that it is far beyond it to explain.

But, he says, although it cannot be observed by the senses, yet we can nonetheless conceive that this is so by the knowledge we have of matter; and we must not hesitate, he says, to base our judgement on things we

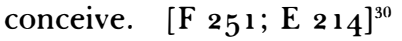

Descartes is said here to argue two things: (1) we can neither understand nor imagine the infinite divisibility of matter because the understanding is finite; (2) yet we do "conceive" it by the "knowledge" we have of matter. To this there are several obvious responses. First, what is "conception" if it is neither understanding nor imagination? If it means "to have a concept in the mind," it is close to either these first two or to judgment itself: the first are both denied, and if it is the last the argument is tautological "fix our judgment on things we judge"). If it means "conceive" in the sense of "perceive" then the argument is contradictory since it denies the action of the senses. $^{31}$

We are not concerned here with what Descartes may really have said but only with the use that is made of his name in the novel. If "conceive" is taken to refer simply to the "so clear principles" (as it presumably does), then the narrator has already resolved the question 'externally' (the other matters all being internal to Campanella's relating of Descartes's arguments). For the entire structure of the novel denies any claim that knowledge is based on such principles, having asserted that the only way to obtain any knowledge about matter is through the senses (see F 101-5, 204, and passim; E 83-86, 205). This 'answer' on the part of the narrator is confirmed when Campanella follows up the passage just quoted with a question whose answer he takes to be negative: "Can we actually imagine the manner in which the soul acts upon the body?" (F 251; E 214). To this the narrator would have been able to answer "yes we can, because the material which composes both is the same, being merely different combinations of atoms" (see, for example, F 120-21, 179-81,

3o. "Vous vous souvenez bien qu'il dit que notre entendement est fini. Ainsi la matière étant divisible à l'infini, il ne faut pas douter que c'est une des choses qu'il ne peut comprendre ni imaginer, et qu'il est bien au-dessus de lui d'en rendre raison. Mais, dit-il, quoique cela ne puisse tomber sous les sens, nous ne laissons pas de concevoir que cela se fait par la connaissance que nous avons de la matière; et nous ne devons pas, dit-il, hésiter à déterminer notre jugement sur les choses que nous concevons."

31. I discuss the question of the meaning of concevoir and its role in Descartes's epistemology in "The concevoir Motif in Descartes," in La cohérence intérieure, ed. J. Van Baelen and D. L. Rubin (Paris, 1977), pp. 203-22. 
193-95; E 99-100, 152-53, 164-65). But at this point Campanella sees that Dyrcona is not following Descartes's reasoning as he relates it and he remarks that this is because the latter cannot purify his mind of his body, it having sunk so low that it now needs the senses for any kind of knowledge. For Dyrcona mind and body, as I suggest, are the same basic substance, and this remark obviously calls for a response on his part. Just as he is about to make one, however, Campanella abruptly changes the subject $(\mathrm{F} \mathrm{251-52;} \mathrm{E} \mathrm{215).} \mathrm{In} \mathrm{one}$ way, the 'failure' of the method of Descartes is emphasized at the end of the novel, where silence falls as he and Campanella start to exchange their ideas (F 272; E 232).

None of this has anything to do with the narrator's admiration for the French philosopher-if it matters. It is a question of the best method for the production of a knowledge of nature. Socrates's demon affirms, "I should like to show you by experience that this is so" ( $\mathrm{F}_{52} ; \mathrm{E} 4 \mathrm{O}$ ), while in Colignac's dream at the beginning of the Soleil, Nature, seeing the persecution of Dyrcona, cries out, "Alas! . . he is one of my friends!" (F 138; E 1 14). It is to Nature, or chance her agent, that the narrator himself constantly turns for guidance (see, for example, $\mathrm{F} 41,179$; E 29, 152). Yet perhaps this contradiction between what is the right method for Bacon or Galileo on the one hand and for Descartes on the other only seems to be a contradiction, which is why the narrator's admiration is undiminished.

The aim in all is possession and control of nature, by the $I$ of enunciation, by means of a discourse adequate to concepts and things; the method in all involves the same elements. The difference is the respective weight given to each and to their order. It is here that the narrator's ambiguity toward Descartes comes into ironic play. Descartes elaborates a method and its axioms before experimentation, and there is little play between ordered experiment and 'first' principles-although there certainly is between experience (as opposed to 'experiment') and the setting into order of such principles, undertaken initially out of dissatisfaction with and to overthrow the false knowledge passed on by his teachers' authority. This is not excessively different from what we find in Galileo, though there some play between experiment and theory continues later 'down' the sequence. In Bacon this play, this 'dialectic of knowing,' continues even further down the sequence. This, it seems to me, is the essential difference and why it is possible for the narrator to praise them all (though the name of Bacon is not actually mentioned).

The "father" has been overthrown and replaced by the son, and rightly, say the lunarians. For the father blocks the son's liveliness, 
the manifestation of his courage, of his strength, of his quickness of mind and imagination, of his virile relationship with nature $(\mathrm{F}$ 79-84; E 63-68). The son, then, is at liberty to "walk upon the belly of the father that begot" him ("sur le ventre du père qui [l']engendra," F 81; E 65). The son(s) has given birth to an open-ended, developing method: a potentially endless repetition of the same structure, each time filled out with different and sequential variables, and leading to an unlimited expansion of knowledge (though Bacon and Descartes, at least, both suggest a distant future when there will no longer be any available new variables, when all will be known). The Voyages of Cyrano de Bergerac are the novels of the son. After New Atlantis itself, they are the first fictional evidence of the "masculine" birth. ${ }^{32}$

32. A recent thesis has sought to assimilate the novels to "the tradition of the Menippean satire" and is of course quite dissimilar to the analysis just presented in this chapter: Judy Carol Walker, "The Unity of Cyrano de Bergerac's Imaginary Voyages" (Ph.D. diss., University of Kentucky, 1974; Ann Arbor, 1975), p. 172. Such an assimilation strikes me as ignoring the historical specificity of the novels, even though her argument that they each follow a threefold ordering of "demystification," "chastisement," and subsequent "re-education" may seem to bear some slight resemblance to my discussion of experimentalism. But her discussion deals only with the gross ordering of the texts, so as to be able to align them with the literary tradition of the Menippean satire. That she can only deal with such "macro-organization" seems to be a consequence of trying to assimilate all "literary" texts to "their own" tradition seen as in some sense outside history-a matter to which I will return in Chapter 12. A more subtle attempt to see a novel contemporary with Cyrano's as Menippean satire, and at the same time to insert it into its specific historical context (following Bakhtin, therefore, rather than Frye), is Joan De Jean, Scarron's "Roman comique": A Comedy of the Novel, A Novel of Comedy (Berne, Frankfurt, and Las Vegas, 1977). 